\title{
The aconitase of Escherichia coli: purification of the enzyme and molecular cloning and map location of the gene (acn)
}

\author{
Chrisostomos Prodromou, Megan J. Haynes and John R. Guest* \\ The Krebs Institute for Biomolecular Research, Department of Molecular Biology and Biotechnology, \\ University of Sheffield, PO Box 594, Firth Court, Western Bank, Sheffield S10 2UH, UK
}

(Received 24 April 1991; revised 10 July 1991; accepted 24 July 1991)

\begin{abstract}
The aconitase of Escherichia coli was purified to homogeneity, albeit in low yield (0.6\%). It was shown to be a monomeric protein of $M_{\mathrm{r}} \mathbf{9 5 0 0 0}$ or 97500 by gel filtration and SDS-PAGE analysis, respectively. The $\mathbf{N}$-terminal amino acid sequence resembled that of the Bacillus subtilis enzyme (citB product), but the similarity at the DNA level was insufficient to allow detection of the $E$. coli acn gene using a 456 bp citB probe. Phages containing the acn gene were isolated from a $\lambda-E$. coli gene bank by immunoscreening with an antiserum raised against purified bacterial enzyme. The acn gene was located at $28 \mathrm{~min}(1350 \mathrm{~kb})$ in the physical map of the $E$. coli chromosome by probing Southern blots with a fragment of the gene. Attempts to locate the gene using the same procedure with oligonucleotide probes encoding segments of the $\mathrm{N}$-terminal amino acid sequence were complicated by the lack of probe specificity and an inaccuracy in the physical map of Kohara et al. (Cell 50, 495-508, 1987). Aconitase specific activity was amplified some 20-200-fold in cultures transformed with pGS447, a derivative of pUC119 containing the acn gene, and an apparent four-fold activation-deactivation of the phagemid-encoded enzyme was observed in late exponential phase. The aconitase antiserum cross-reacted with both the porcine and Salmonella typhimurium $\left(M_{\mathrm{r}}\right.$ 120000) enzymes.
\end{abstract}

\section{Introduction}

Aconitase or citrate (isocitrate) hydro-lyase (EC 4.2.1.3) functions in both the citric acid and glyoxylate cycles. It is a dehydratase-hydratase which catalyses the reversible isomerization of citrate and isocitrate via cisaconitate. The mitochondrial aconitases have been purified from a variety of sources and shown to be monomeric proteins with an $M_{\mathrm{r}}$ of about $79000-83000$ : porcine heart (Villafranca \& Mildvan, 1971; Zheng et al., 1990); bovine heart (Ryden et al., 1984); and Saccharomyces cerevisiae (Scholze, 1983; Gangloff et al., 1990). In contrast, the fluoroacetate-induced enzyme from Candida lipolytica seems to be smaller, $M_{\mathrm{r}} 68500$ (Suzuki et al., 1975), and the Bacillus subtilis enzyme is considerably larger, $M_{\mathrm{r}} 120000$ (Dingman \& Sonenshein, 1987).

Aconitase is interesting because it contains a cubanelike [4Fe-4S] cluster which is redox inactive, and essential for activity. Indeed, one of the Fe atoms (designated $\mathrm{Fe}_{\mathrm{a}}$ ), has been shown to coordinate with the middle carboxyl group, and possibly the hydroxyl group, of the substrate (Kennedy et al., 1987; Werst et al.,

Abbreviations: ICDH, isocitrate dehydrogenase; TC, Tris/citrate.
$1990 a, b)$. Exposure to oxygen during purification results in the loss of the $\mathrm{Fe}_{\mathrm{a}}$ atom, producing a catalytically inactive enzyme with a $[3 \mathrm{Fe}-4 \mathrm{~S}]^{+}$cluster. However, the enzyme can be partially protected by adding citrate during purification, or reactivated by $\mathrm{Fe}^{2+}$ under reducing conditions to give a $[4 \mathrm{Fe}-4 \mathrm{~S}]^{2+}$ cluster (Emptage et al., 1983; Kennedy et al., 1983; Kennedy \& Bienert, 1988). The structures of the inactive [3Fe-4S] and active [4Fe-4S] forms of the porcine heart enzyme have been solved at 0.21 and $0.25 \mathrm{~nm}$ resolution, respectively (Robbins \& Stout, $1989 a, b$ ).

The gene encoding the mitochondrial aconitase of $S$. cerevisiae has recently been cloned and the primary structure of the enzyme has been deduced from its nucleotide sequence (Gangloff et al., 1990). Similarly, the amino acid sequence of porcine heart aconitase has been deduced from the nucleotide sequence of the corresponding cDNA (Zheng et al., 1990) and the N-terminal region of the $B$. subtilis enzyme has been deduced from a segment of the citB gene (Rosenkrantz et al., 1985; Dingman \& Sonenshein, 1987).

Very little is known about the Escherichia coli aconitase and studies on the aconitase gene (acn) have been hindered by the lack of mutants deficient in aconitase. Genes encoding all of the citric acid cycle 
enzymes except aconitase have been cloned, sequenced and located in the E. coli chromosome (Miles \& Guest, 1987; Bachmann, 1990). Several strategies have now been used to clone the acn gene and then to explore the possibility that aconitase is related to the oxygen-labile [4Fe-4S]-containing fumarases (Woods et al., 1988; Bell et al., 1989; Flint et al., 1989). An M13 derivative containing part of the aconitase gene (citB) of $B$. subtilis was used as a hybridization probe in previous attempts to clone the aconitase gene (acn) of $E$. coli (Wilde et al., 1986). Several putative $\lambda a c n$ phages were isolated and characterized by their ability to amplify aconitase 5-18fold upon prophage induction. These phages were subsequently found to contain segments of the lac operon and the reason for their ability to amplify aconitase remains obscure (Wilde, 1988). More recently, two sets of weakly hybridizing fragments were detected in digests of $E$. coli DNA, using a purified $456 \mathrm{bp}$ cit $B$ probe (C. Prodromou, unpublished observations). One corresponded to the lac region of the physical map (Kohara $e t$ al., 1987), possibly because the probe was contaminated with fragments of lac DNA, and the other was traced to the recC and ptrIII genes at $61 \mathrm{~min}$. These genes each contain a small sequence that is similar to part of the citB probe: ATCTGGCTTCACTGCTAAtGCA in recC and AACCCTtATATTCCTGaTGATtTC in ptrIII (Finch et al., 1986a,b). Because the citB probe failed to detect the acn gene of $E$. coli, alternative strategies were adopted based on the purification of aconitase and the use of (i) oligonucleotide probes encoding $\mathrm{N}$-terminal sequences and (ii) immunochemical probes.

This paper reports the purification of the $E$. coli aconitase and the successful isolation, identification and map location of the corresponding gene.

\section{Methods}

Bacteria, plasmids and bacteriophages. The strains of E. coli $\mathrm{K} 12$ were: W3110 (wild-type); DH1 (thi-1 hsdR17 supE44 recAl endAl gyrA96 relAl), the routine transformation host; $\mathrm{C} 600$ (thr-1 leuB6 thi-I lacYI supE44 hsdR tonA2l) as the general host for $\lambda$ phages; and NM621 (leu pro thi supE hsd $\mathrm{Rcr} \mathrm{B}^{+} \mathrm{A}^{-}$recD 1009 ton tsx), kindly provided by $\mathrm{Dr} \mathrm{M}$. Masters (University of Edinburgh) for propagating phages from the $E$. coli W 3110 gene library (Kohara et al., 1987). The $E$. coli $\mathrm{C} 600$ gene library was provided by Dr P. T. Emmerson (University of Newcastleupon-Tyne): it contained partially Sau3A-digested bacterial DNA inserted into the BamHI site of the $\lambda$ PE11 replacement vector (Arthur et al., 1982). A copy of the E. coli W3110 gene library (Kohara et al., 1987) was provided by D. Buck (Schering, Saffron Walden, Essex). The $\lambda E M B L 4$ derivatives, $\lambda 13 \mathrm{~F} 9$ and $\lambda 18 \mathrm{~B} 6$ [254 and 255 in the 'mini-set' of Kohara et al. (1987)], were used for subcloning the acn gene into the phagemid vector pUC119. A derivative of M13 (M13mp10-KJ9; Wilde et al., 1986), which contains part of the Bacillus subtilis aconitase gene (citB), was the source of the citB probe, a 456 bp PstI-EcoRI fragment encoding 152 amino acid residues close to the $\mathrm{N}$-terminus of the enzyme.
DNA from $E$. coli, bacteriophages and phagemids was prepared and manipulated as described by Maniatis et al. (1982).

Purification of aconitase. Aconitase was purified from E. coli W3110 grown with vigorous aeration at $37^{\circ} \mathrm{C}$ for $13 \mathrm{~h}$ using $1 \%(\mathrm{v} / \mathrm{v})$ inocula (Tryptone Soya Broth, Oxoid) in $16 \times 500 \mathrm{ml}$ complex malate medium to obtain a high level of aconitase expression (Gray et al., 1966). Subsequent steps were performed at $4{ }^{\circ} \mathrm{C}$ and a citrate-containing buffer (TC; Tris/citrate, $20 \mathrm{~mm}, \mathrm{pH} \mathrm{8.0)}$ was used to protect the enzyme. The bacteria were harvested $(14000 \mathrm{~g}$ for $15 \mathrm{~min})$, washed and resuspended ( $1 \mathrm{~g}$ wet $\left.\mathrm{wt} \mathrm{ml}^{-1}\right)$ in $\mathrm{TC}$ buffer and then disrupted by three passes through a French pressure cell (20000 p.s.i.: $138 \mathrm{~Pa})$. The extract was clarified by centrifugation at $20000 \mathrm{~g}$ for $30 \mathrm{~min}$ and $150000 \mathrm{~g}$ for $2 \mathrm{~h}$.

The cell extract was fractionated with $\left(\mathrm{NH}_{4}\right)_{2} \mathrm{SO}_{4}$ at $35-50 \%$ saturation and the pellet fraction $(15000 \mathrm{~g}$ for $30 \mathrm{~min})$ solubilized in $47 \mathrm{ml}$ TC buffer. A sample $(23.5 \mathrm{ml})$ was mixed with an equal volume of $2 \mathrm{M}-\left(\mathrm{NH}_{4}\right)_{2} \mathrm{SO}_{4}$ and loaded at $0.5 \mathrm{ml} \mathrm{min}^{-1}$ on a Phenyl Sepharose CL-4B column $(80 \times 2.6 \mathrm{~cm})$ previously equilibrated with TC buffer containing $1 \mathrm{M}-\left(\mathrm{NH}_{4}\right)_{2} \mathrm{SO}_{4}$. The column was washed with $200 \mathrm{ml}$ of $1 \mathrm{M}-\left(\mathrm{NH}_{4}\right)_{2} \mathrm{SO}_{4}$ in TC buffer and bound aconitase was eluted using an $800 \mathrm{ml}$ linear gradient of $1.0-0 \mathrm{M}-\left(\mathrm{NH}_{4}\right)_{2} \mathrm{SO}_{4}$ in $\mathrm{TC}$ buffer at a flowrate of $3 \mathrm{ml} \mathrm{min}^{-1}$. The active fractions from two columns were concentrated by ultrafiltration in a stirred cell (Filtron, omegacell) with a $3 \mathrm{kDa}$ nominal molecular mass limit. The concentrated sample $(4.0 \mathrm{ml}$ approx.) was fractionated by gel-filtration on a Sephacryl S-200 HR column $(80 \times 2.6 \mathrm{~cm})$ equilibrated in MES/Mg buffer $(10 \mathrm{mM}-\mathrm{MES} /$ $\mathrm{KOH}, \mathrm{pH} 6.0$, with $5 \mathrm{mM}-\mathrm{MgCl}_{2}$ ) containing sodium citrate $(10 \mathrm{mM}$, pH 6.0) and eluted at $0.5 \mathrm{ml} \mathrm{min}^{-1}$ with the same buffer. Active fractions were pooled and concentrated approximately fivefold (to $8.5 \mathrm{ml}$ ) by ultrafiltration, as above. The sample was then diluted with 10 vols of MES/Mg buffer in order to reduce the concentration of residual citrate before applying to a Procion Red dye affinity column $(26 \times 1.6 \mathrm{~cm})$. A weakly-active fraction failed to bind, and pure active enzyme was eluted (1-2 $\left.\mathrm{ml} \mathrm{min}^{-1}\right)$ with a linear gradient of 0-100 mMcitrate in MES/Mg buffer. Protein was assayed by the procedure of Bradford (1976).

Determination of $M_{r} . M_{\mathrm{r}}$ was determined by SDS-PAGE and gel filtration on the Sephacryl S-200 HR column $(80 \times 2.6 \mathrm{~cm})$ equilibrated and eluted $\left(0.5 \mathrm{ml} \mathrm{min}^{-1}\right)$ with TC buffer. The column was calibrated with standard proteins $\left(M_{\mathrm{r}}\right): \beta$-amylase $(200000)$; alcohol dehydrogenase (150000); carbonic anhydrase $(29000)$; cytochrome $c(12300)$. The standards for SDS-PAGE were $\left(M_{\mathrm{r}}\right): \beta$-galactosidase $(116000)$; fructose-6-phosphate kinase (84000); ovotransferrin (76000-78000); bovine serum albumin (66250); pyruvate kinase $(64000)$; ovalbumin (48000 and 45000); lactate dehydrogenase (36400); triose-phosphate isomerase (29700); carbonic anhydrase (29000); myoglobin (17200); cytochrome $c$ (12300).

Enzyme assays. Aconitase was assayed spectrophotometrically at $240 \mathrm{~nm}$ by following the formation of cis-aconitate from isocitrate, as described by Kennedy et al. (1983). An absorption coefficient of $3.6 \mathrm{~mm}^{-1}$ was used, and 1 unit (U) of activity was equal to $1 \mu \mathrm{mol}$ of cisaconitate formed $\mathrm{min}^{-1} \mathrm{ml}^{-1}$. In reactivation studies, extracts, prepared in Tris/ $\mathrm{HCl}(20 \mathrm{mM}, \mathrm{pH} 8)$ or TC buffers, were incubated at $4{ }^{\circ} \mathrm{C}$ with $5 \mathrm{~mm}$-dithiothreitol and $0.5 \mathrm{~mm}-\mathrm{Fe}\left(\mathrm{NH}_{4}\right)_{2}\left(\mathrm{SO}_{4}\right)_{2}$, and assayed at $10 \mathrm{~min}$ intervals. An activity stain for aconitase in nondenaturing polyacrylamide gels was performed by coupling the conversion of cis-aconitate to isocitrate to a colorimetric test for isocitrate dehydrogenase (ICDH). Samples containing aconitase were fractionated in $8 \%(w / v)$ non-denaturing polyacrylamide gels. The test gel was immersed in $32 \mathrm{ml}$ of the linked assay reagent containing: $10 \mathrm{U}$ ICDH; $12 \mathrm{mg}$ tetranitroblue tetrazolium; $15 \mathrm{mg}$ NADP; $1 \mathrm{mg}$ phenazine methosulphate; $2.5 \mathrm{mM}-\mathrm{MCl}_{2} ; 125 \mathrm{mM}$-Tris/HCl, pH 8.0; $12.5 \mathrm{~mm}$-cis-aconitate; and $10 \%(\mathrm{w} / \mathrm{v})$ gelatine. A control gel was 
incubated without cis-aconitate, and another was incubated with isocitrate instead of cis-aconitate and with no ICDH, in order to stain for ICDH activity.

$N$-terminal amino acid sequence analysis and oligonucleotide probes. The N-terminus of aconitase was sequenced by automated Edman degradation (Laursen, 1971) at the SERC Amino Acid Sequencing Facility (Department of Biochemistry, University of Leeds). Two pairs of mixed oligonucleotide probes were designed to encode overlapping segments of the N-terminal sequence: S135 (AA[AG] GA[TC] AC[GTAC] TT[AG] CA[AG] GC) and S136 (AA[AG] GA[TC] AC[GTAC] CT[GTAC] CA[AG] GC) encode K-D-T-L-Q-A but use different sets of Leu codons; whereas $\mathrm{S} 139$ (GA[AG] GC[GTAC] TC[GTAC] AA[AG] GA[TC] AC) and S140 (GA[AG] GC[GTAC] AG[TC] AA[AG] GA[TC] AC) encode E-A-S-K-D-T using different Ser codons.

Southern blotting and DNA hybridization. Southern blotting was carried out according to Southern (1975) and $\lambda$ plaques and colonies containing pGS447 and pGS448 were transferred and fixed to nitrocellulose as described by Maniatis et al. (1982). A transfer procedure which avoids depurination (Meinkoth \& Wahl, 1984) was used with the oligonucleotide probes. The cit $B$ probe was labelled by incorporating digoxigenin-11-dUTP into a complementary strand of M13mp10-KJ9 by primer extension ( 1.2 pmol universal primer per $\mu \mathrm{g}$ template) and the $456 \mathrm{bp} \mathrm{PstI-EcoRI} \mathrm{fragment} \mathrm{was} \mathrm{released} \mathrm{and} \mathrm{then}$ purified by electrophoresis in $0.5 \%$ agarose. Hybridizations were for $16 \mathrm{~h}$ at 55,60 and $65^{\circ} \mathrm{C}$, the filters were washed twice at the hybridization temperature for $15 \mathrm{~min}$ with $2 \times$ SSC solution $(17.53 \mathrm{~g}$ $\mathrm{NaCl}$ and $8.82 \mathrm{~g}$ sodium citrate in 1 litre, $\mathrm{pH} \mathrm{7.0)}$ ) and immunodetection was according to the instructions supplied with the Non-Radioactive Labelling Kit (Boehringer Mannheim). The $400 \mathrm{bp}$ BamHI-EcoRI fragment of $\lambda \mathrm{G} 229$ and the $3.2 \mathrm{~kb} \mathrm{BamHI}$ fragment of $\lambda 13 \mathrm{~F} 9$ were subcloned into M13mp18 ( $\mathrm{CP1}$ and $\mathrm{CP} 2$, respectively) and then labelled and excised to give probes $\mathrm{BE} 1$ and $\mathrm{BB} 1$ (respectively) as for the $c i t B$ probe. Hybridization with these probes was for $4 \mathrm{~h}$ at $65^{\circ} \mathrm{C}$ and the filters were washed with $2 \times \mathrm{SSC}$ for $15 \mathrm{~min}$ at room temperature, and twice with $0 \cdot 1 \times \mathrm{SSC}$ for $15 \mathrm{~min}$ at $65^{\circ} \mathrm{C}$.

Oligonucleotides were labelled with $\left[\gamma^{-32} \mathrm{P}\right] \mathrm{dATP}$ using the procedure of Arrand (1985) and hybridization was detected by autoradiography. The hybridization temperatures were calculated as $5{ }^{\circ} \mathrm{C}$ below the predicted $T_{\mathrm{d}}$ (Mason \& Williams, 1985 ): $39^{\circ} \mathrm{C}$ for $\mathrm{S} 135 ; 41^{\circ} \mathrm{C}$ for $\mathrm{S} 136$; and $41^{\circ} \mathrm{C}$ for the combination of $\mathrm{S} 139$ plus $\mathrm{S} 140$. The filters were washed with $6 \times \mathrm{SSC}$ for $15 \mathrm{~min}$ at $14^{\circ} \mathrm{C}$ and then for $1 \mathrm{~min}$ at 44 (S135) or $46^{\circ} \mathrm{C}$ (S136, and S139 plus S140).

Gel electrophoresis and immunological techniques. PAGE was performed as described by Laemmli (1970), using denaturing conditions $(0.1 \%$ SDS in all buffers and 10 or $6 \%$ acrylamide) or non-denaturing conditions (no SDS and $8 \%$ acrylamide) and biotinylated size markers $\left(M_{\mathrm{r}}\right)$ : phosphorylase b $(97400)$; catalase $(58100)$; alcohol dehydrogenase (39800); carbonic anhydrase (29000). For Western blotting, samples in SDS-polyacrylamide gels were transferred to nitrocellulose with a Bio-Rad Transblot Electrophoretic Transfer Cell according to the manufacturer's instructions.

The aconitase used for raising antiserum was excised from a polyacrylamide gel (SDS-PAGE, $6 \%$ ) which had been lightly stained with $0.2 \%$ Coomassie blue R-250 in the absence of methanol and acetic acid. The gel slice was frozen in liquid $\mathrm{N}_{2}$, crushed to a fine powder, and mixed with an equal volume of Freund's complete adjuvant for injecting a rabbit. Assays for enzyme inactivation were performed by mixing $1-100 \mu \mathrm{l}$ serum with 2 units aconitase in a final volume of $1.0 \mathrm{ml}$ $20 \mathrm{~mm}$-Tris/ $\mathrm{HCl}, \mathrm{pH} 7 \cdot 0$. The mixtures were incubated for $30 \mathrm{~min}$ at $4{ }^{\circ} \mathrm{C}$, centrifuged for $10 \mathrm{~min}$ at $15000 \mathrm{~g}$, and the supernatant fluids assayed for aconitase activity.

For plaque hybridization, samples of the $\lambda$ PE $11 E$. coli library were plated on E. coli $\mathrm{C} 600\left(5 \times 10^{2}\right.$ p.f.u. per plate). The plates were incubated at $37^{\circ} \mathrm{C}$ for $5-6 \mathrm{~h}$, overlaid with a nitrocellulose filter and incubated for a further 4-6h, before fixing (Maniatis et al., 1982). The procedure for immunological detection with nitrocellulose filters from Western blots and plaque lifts was performed at room temperature as described by Andrews $e t$ al. (1989). The dilutions of the primary antiserum and the biotinylated anti-rabbit antibody were 1:1000 and $1: 500$, respectively, while that of the streptavidin-biotinylated horseradish peroxidase complex was $1: 3000$.

Analysis of aconitase activity in $\lambda$-infected bacteria and phagemid transformants. Cultures of $E$. coli $\mathrm{C} 600$ were grown to an $\mathrm{OD}_{650}$ of 0.2 in $20 \mathrm{ml} \mathrm{LB}$ broth (Maniatis et al., 1982) containing $0.2 \%$ maltose and $10 \mathrm{~mm}-\mathrm{MgSO}_{4}$. The cultures were concentrated 20 -fold in $10 \mathrm{~mm}$ $\mathrm{MgSO}_{4}$ for phage adsorption (15 min at room temperature with an m.o.i. of 2) and diluted into $20 \mathrm{ml}$ prewarmed LB broth containing $10 \mathrm{~mm}-\mathrm{MgSO}_{4}$. The infected bacteria were incubated at $37^{\circ} \mathrm{C}$ with shaking, and samples $(1.5 \mathrm{ml})$ were pelleted $(15000 \mathrm{~g}$ for $2 \mathrm{~min})$ and stored at $20^{\circ} \mathrm{C}$ prior to analysis.

Phagemid transformants of $E$. coli $\mathrm{DH} 1$ were cultured by shaking at $37^{\circ} \mathrm{C}$ in $50 \mathrm{ml} \mathrm{LB}$ broth containing ampicillin $\left(200 \mu \mathrm{g} \mathrm{ml}^{-1}\right)$ and sampled as described for the phage-infected bacteria. The pelleted bacteria were resuspended in $300 \mu \mathrm{l} \mathrm{TC}$ buffer. Of this, $200 \mu \mathrm{l}$ was disrupted by ultrasonication $(30 \mathrm{~s}, 10 \mu \mathrm{m})$ and the clarified supernatant assayed for aconitase activity and protein. The remainder was stored at $-20^{\circ} \mathrm{C}$ for SDS-PAGE and Western blotting in which each lane contained the equivalent of $10 \mu \mathrm{l}$ of a suspension with an $\mathrm{OD}_{650}$ of 1.0 . The results were reproducible within narrow limits for each type of experiment and typical sets are presented.

DNA-directed transcription-translation. Purified double-stranded pUC119 and pGS447 DNA was used for in vitro transcriptiontranslation according to the instructions supplied with the Prokaryotic DNA-directed Translation Kit (Amersham).

Materials. Isocitric acid, cis-aconitic acid, tetranitroblue tetrazolium, phenazine methosulphate, isocitrate dehydrogenase, $\beta$-galactosidase and alcohol dehydrogenase were obtained from Sigma. Alkaline phosphatase, NADP, T4 DNA ligase, DNA polymerase (Klenow enzyme) and the Non-Radioactive Digoxigenin Labelling Kit were purchased from Boehringer Mannheim. Biotinylated anti-rabbit antibody, streptavidin-biotinylated horseradish peroxidase complex, the Prokaryotic DNA-Directed Translation Kit, L-[ ${ }^{35}$ S $]$ methionine and $\left[\gamma^{-32} \mathrm{P}\right] \mathrm{dATP}$, were obtained from Amersham. Molecular mass markers for SDS-PAGE were obtained from BDH, and the prestained SDS-PAGE-, gel-filtration and biotinylated-markers were from Sigma. Restriction enzymes were purchased from Northumbria Biologicals. Oligonucleotides were synthesized with an Applied Biosystems 381 A DNA synthesizer. The Procion Red matrix was prepared as follows: $200 \mathrm{ml}$ Procion Red H-3B (1\%,w/v: ICI) was added to $200 \mathrm{ml}$ Sepharose CL-6B and stirred occasionally for $30 \mathrm{~min}$ before adding $100 \mathrm{ml} \mathrm{NaCl}(20 \%, \mathrm{w} / \mathrm{v})$ and $5 \mathrm{ml} 5 \mathrm{M}-\mathrm{NaOH}$ after a further $30 \mathrm{~min}$. The slurry was left for $3 \mathrm{~d}$ at room temperature and then washed sequentially with $1 \mathrm{M}-\mathrm{NaCl}$ and $6 \mathrm{M}$-urea to remove unreacted dye.

\section{Results}

\section{Purification and characterization of aconitase}

Studies with crude extracts prepared in the presence and absence of citrate showed that the former were $2 \cdot 5$-fold more active, and that the aconitase activities of the latter could be reactivated to the citrate-protected level by incubating with ferrous ions under reducing conditions. 


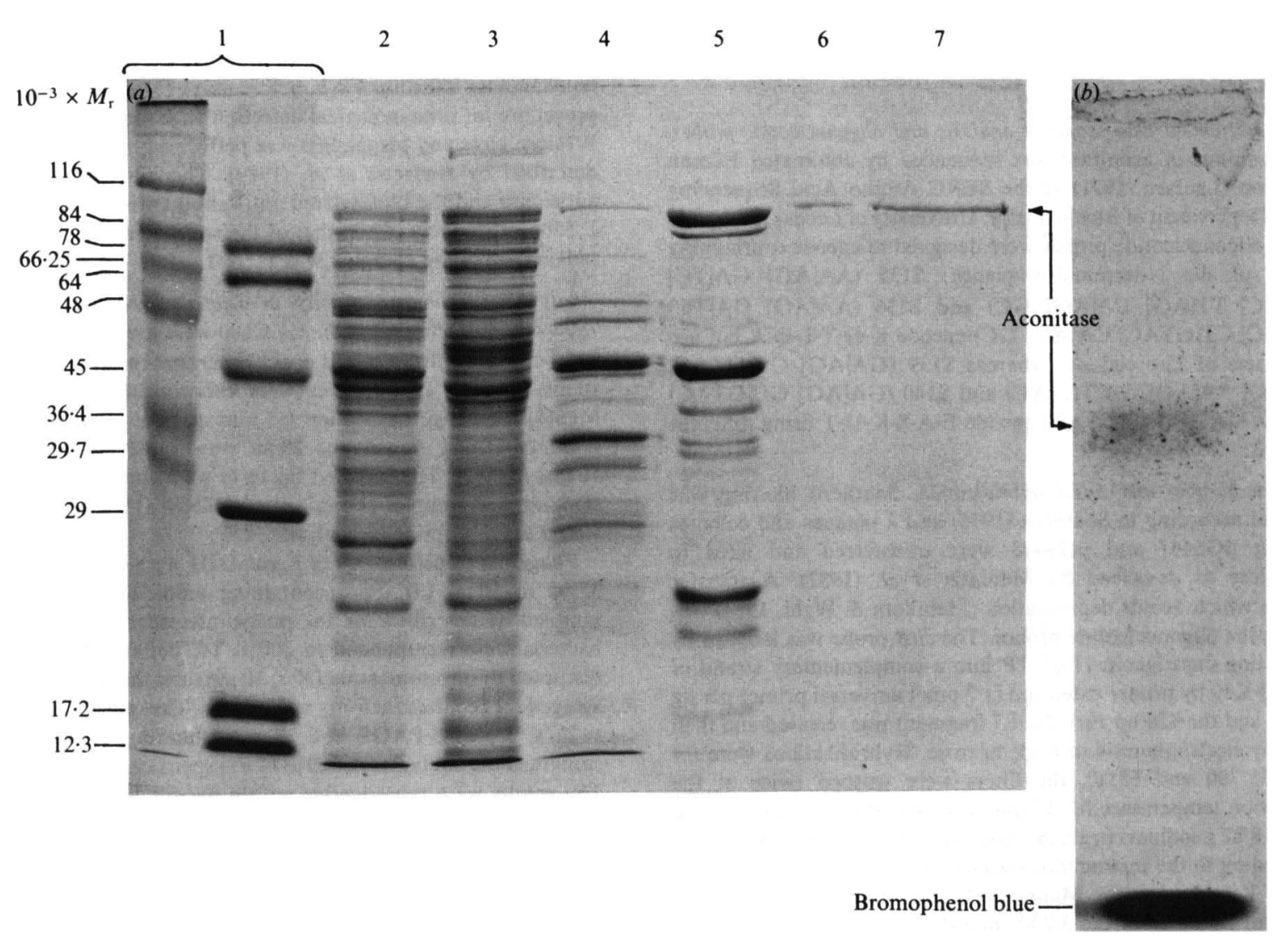

Fig. 1. Purification and activity-staining of the E. coli aconitase. (a) Coomassie-stained SDS-PAGE ( $10 \%$ gel) showing samples of active fractions at different stages of purification. Lanes: 1 , molecular mass standards; 2, cell-free extract; 3 , ammonium sulphate precipitate; 4, Phenyl Sepharose; 5, Sephacryl; 6, Procion Red (unbound); 7, Procion Red (bound). (b) Activity-stained non-denaturing PAGE $\left(8 \%\right.$ gel) of a sample at the Sephacryl-purified stage. The protein in the active band migrated at $M_{\mathrm{r}} 97500$ when excised and analysed by SDS-PAGE, as indicated.

Table 1. Purification of aconitase from E. coli W3110

\begin{tabular}{lccccc}
\hline \hline \multicolumn{1}{c}{$\begin{array}{c}\text { Purification } \\
\text { step }\end{array}$} & $\begin{array}{c}\text { Total } \\
\text { activity } \\
(\mathrm{U})^{*}\end{array}$ & $\begin{array}{c}\text { Total } \\
\text { protein } \\
(\mathrm{mg})\end{array}$ & $\begin{array}{c}\text { Specific } \\
\text { activity } \\
\left(\mathrm{U} \mathrm{mg} \mathrm{m}^{-1}\right)\end{array}$ & $\begin{array}{c}\text { Yield } \\
(\%)\end{array}$ & $\begin{array}{c}\text { Purification } \\
\text { (-fold) }\end{array}$ \\
\hline Cell extract & 2700 & 8380 & 0.32 & 100 & 1.00 \\
(NH $\left._{4}\right)_{2} \mathrm{SO}_{4}$ ppt. & 2110 & 4130 & 0.51 & 78 & 1.59 \\
Phenyl Sepharose CL-4B & 102 & 74.3 & 1.37 & 3.8 & 4.28 \\
Sephacryl S-200 HR & 20.4 & 15.0 & 1.36 & 0.76 & 4.25 \\
Procion Red (unbound) & 0.6 & 0.46 & 1.30 & $\mathbf{0 . 0 2}$ & 4.06 \\
Procion Red (bound) & 16.2 & 0.66 & $24.5 \dagger$ & $\mathbf{0 . 6 0}$ & $\mathbf{7 6 . 6}$ \\
\hline \hline
\end{tabular}

* Units are $\mu \mathrm{mol}$ cis-aconitate formed $\mathrm{min}^{-1}$.

$\dagger$ Represents a minimum value due to enzyme instability.

This implied that the E. coli enzyme is an iron-sulphur protein resembling the aconitases from other sources. A procedure was devised for purifying $E$. coli aconitase to homogeneity under citrate-protected conditions (see Methods, Table 1 and Fig. 1). The purification was aided by the use of an activity stain which correlated the activity in non-denaturing gel slices with a polypeptide(s) of $M_{\mathrm{r}} 97500$ in SDS-PAGE. Major activity losses occurred during Phenyl Sepharose chromatography and gel filtration, and the overall yield was only $0.6 \%$ despite the use of substrate protection. The final product had a minimum specific activity of $24.5 \mathrm{U}$ (mg protein) $)^{-1}$, 


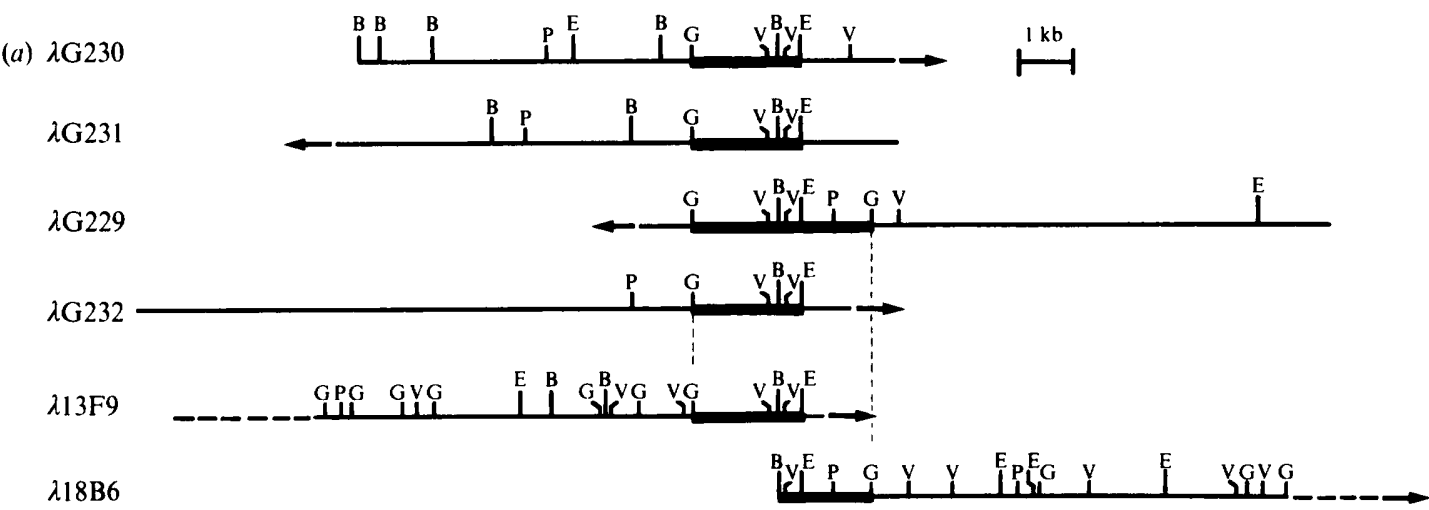

acn coding region

$[D J] \Gamma] \Gamma]$

(b) $\begin{array}{r}\text { pGS445 } \\ \text { pGS447 } \\ \text { pGS448 }\end{array}$

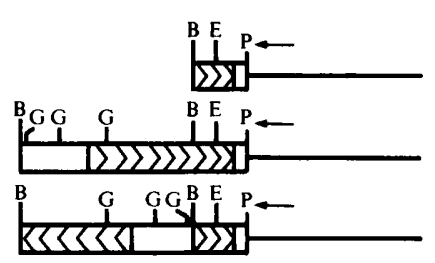

Fig. 2. Restriction maps for the segments of bacterial DNA cloned in putative $\lambda$ acn phages and phagemid derivatives. (a) The maps are aligned on the common 400 bp BamHI-EcoRI fragment (BE1). Those for $\lambda$ G229-232 are incomplete because the $B g l \mathrm{I}(\mathrm{G}), E c o \mathrm{RV}(\mathrm{V})$ and PstI (P) sites were only identified in Southern blots with the BE1 probe. The maps for relevant parts of $\lambda 13 \mathrm{~F} 9$ and $\lambda 18 \mathrm{~B} 6$ (total inserts 17.8 and $17.7 \mathrm{~kb}$, respectively; Kohara et al., 1987) are revised in the region of the BE1 probe. The arrows point towards the right arm of the $\lambda$ vector. The regions common to the $\lambda$ PE11 and $\lambda$ EMBL4 derivatives are indicated by thick lines and the vertical dashed lines. The predicted size and polarity of the aconitase coding region are indicated by hatching within the deduced limits for its location (dashed box). (b) Derivatives of pUC119 containing fragments of $\lambda 13 \mathrm{~F} 9$ and $\lambda 18 \mathrm{~B} 6$ are shown with hatched regions denoting the approximate positions of the aconitase coding region and arrows showing the polarity of the lac promoter. B, BamHI; E, EcoRI.

which corresponds to a purification of at least 76 -fold. Interestingly, most of the active enzyme was bound by the dye affinity matrix whereas an apparently inactive fraction was not bound (Fig. 1). After continued use, the Phenyl Sepharose column gave a non-symmetrical activity-profile, and the enzyme at the leading edge (up to $30 \%$ of total activity) had to be discarded, otherwise the final fractions were contaminated with components of $M_{\mathrm{r}} 21500$ (unbound) and 41500 (bound).

$M_{\mathrm{r}}$ estimates obtained by gel filtration $(95000)$ and SDS-PAGE (97500) indicated that aconitase is a monomeric protein. As shown below, the N-terminal amino acid sequence of the purified enzyme exhibited some degree of similarity with $B$. subtilis aconitase (Dingman \& Sonenshein, 1987) (- denotes an unidentified residue):

$$
\begin{gathered}
\text { E. coli: } \\
\text { - STLREAS KDTLQA-D-T } \\
: *^{*}: * \quad * *
\end{gathered}
$$

\section{B. subtilis: ANEQKTAAKDVFQARKTF}

\section{Studies with oligonucleotide probes}

Knowledge of the $\mathrm{N}$-terminal amino acid sequence of the $E$. coli aconitase allowed the design of two pairs of mixed oligonucleotides for use in locating the acn gene in the physical map of the $E$. coli chromosome (see Methods). One probe (S135) hybridized to the following set of $E$. coli DNA fragments (kb): BamHI, 3.3; BglI, 5.8; EcoRI, 5.2; EcoRV, 1.3; HindIII, 0.7; KpnI, none detected; PstI, $10 \cdot 0$ and $1.7 ; P v u I I 10 \cdot 0$ and $1 \cdot 5$. Very little hybridization was detected with an iso-encoding probe (S136), possibly because it lacks the specific Leu codon of the acn sequence. Unfortunately, the corresponding set of overlapping fragments could not be found in the physical map of the bacterial chromosome (Kohara et al., 1987). Some of the same fragments (italicized above) were amongst those detected by the related probes ( $\mathrm{S} 139$ and S140) but even this limited set could not be found in the map. If it is assumed that the $\mathbf{N}$-terminal sequence is correct, these results suggest that the probes are insufficiently specific for the acn gene or that there are inaccuracies in the acn region of the physical map.

\section{Immunoscreening and map location of the acn gene}

The antiserum used for screening the $\lambda$ PE11-E. coli library gave a strong and reasonably specific reaction with aconitase in Western blots of cell extracts 


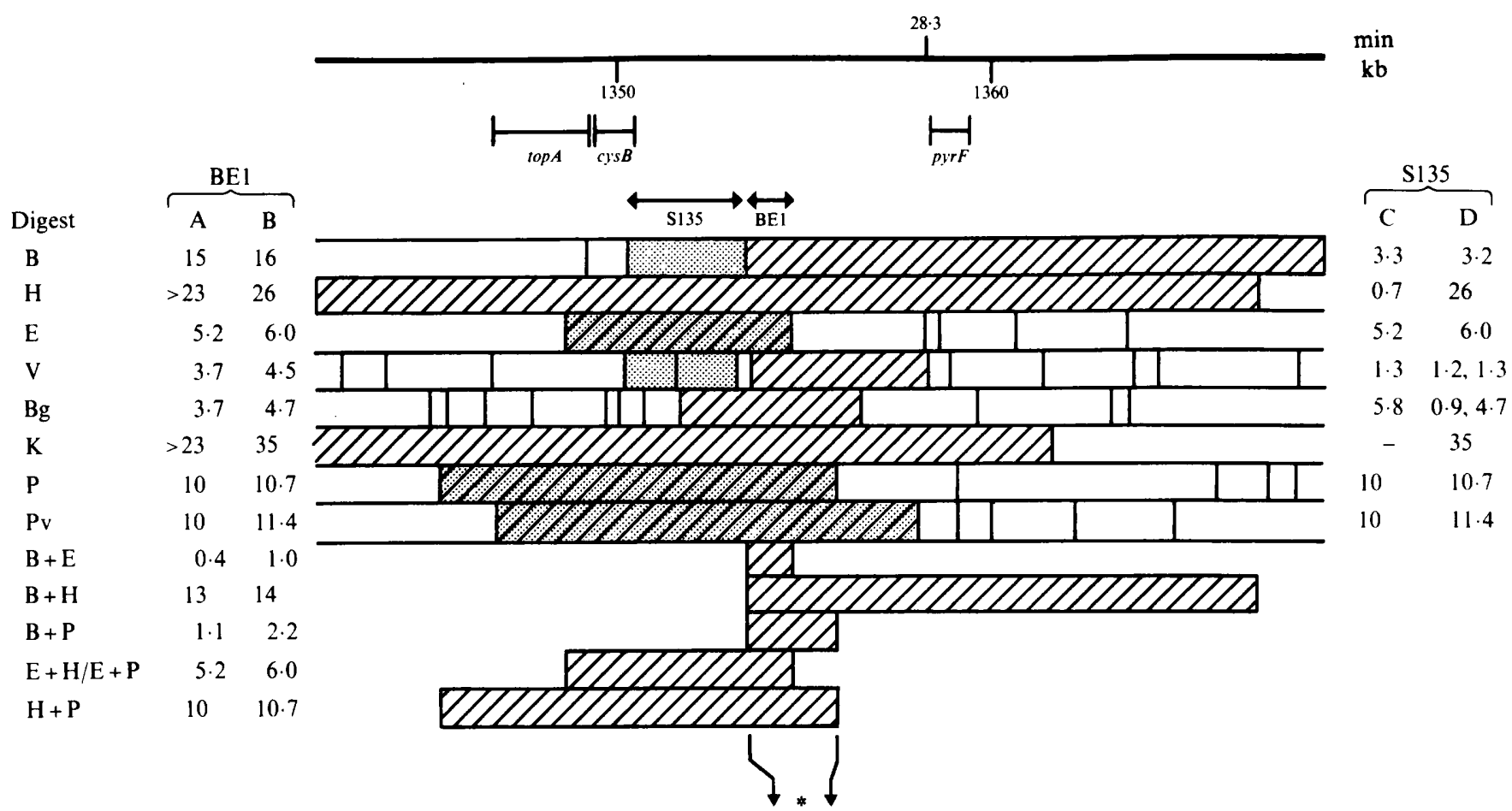

Fig. 3. Physical map in the $28 \mathrm{~min}$ region of the E. coli chromosome according to Kohara et al. (1987). The sizes (kb) of fragments hybridizing with the BEl probe (A) are compared with possible counterparts (B), hatched in the map. The fragments in double digests detected with the same probe are also shown. Some of the fragments (C) hybridizing with an oligonucleotide probe (S135) are likewise compared with predicted counterparts (D), stippled in the map. Limits for the deduced positions of the probes and the positions of specified genes (Kroger et al., 1990) are indicated above the map. The predicted location of an extra $0.8 \mathrm{~kb}$ of DNA in the physical map is indicated by vertical arrows and the asterisk (*). B, BamHI; Bg, BglI ; E, EcoRI; V, EcoRV; H, HindIII; K, KpnI ; P, PstI; Pv, PvuII.

fractionated by SDS-PAGE, although it appeared not to inactivate or precipitate the enzyme under the conditions used (data not shown). In comparable blots, the antiserum cross-reacted with porcine aconitase and with a polypeptide of $M_{\mathrm{r}} 120000$ (approx.) in extracts of Salmonella typhimurium. In plaque hybridizations some 40 out of 7000 plaques were immunopositive and restriction analyses with 16 purified lines showed that 10 contain a common $400 \mathrm{bp}$ BamHI-EcoRI fragment. Based on their restriction maps, these phages fell into four classes, which are represented by $\lambda$ G229-232 in Fig. 2. Five additional classes, which lack the 400 bp BamHI-EcoRI fragment and are represented by $\lambda$ G233237 (not shown), were also detected. This diversity of classes suggests that some considerable rearrangement of the Sau3A partially-digested bacterial DNA fragments had occurred in constructing the $\lambda P E 11$ library. The 400 bp BamHI-EcoRI fragment was subcloned from $\lambda \mathrm{G} 229$ to $\mathrm{M} 13 \mathrm{mp} 18$ for preparing the hybridization probe, BE1. This was used to confirm that each of the four classes of phages contained the identical fragment and to define its chromosomal location.

Southern blotting with BE1 identified a set of $E$. coli DNA fragments which could best derive from the $28 \mathrm{~min}$
$(1350 \mathrm{~kb})$ region of the chromosomal map (Fig. 3). However, there were some significant discrepancies between the observed and predicted sizes, including the size $(1.0 \mathrm{~kb})$ predicted for the $0.4 \mathrm{~kb}$ probe. Nevertheless, the proposed location was supported by the hybridization patterns obtained with double digests of $E$. coli DNA (Fig. 3) and by tests with specific clones from the 'mini-set' of $\lambda$ phages containing the entire $E$. coli genome (Kohara et al., 1987). Plaque hybridizations and Southern blots for $\lambda 4 \mathrm{~F} 1, \lambda 13 \mathrm{~F} 9, \lambda 18 \mathrm{~B} 6, \lambda \mathrm{E} 14 \mathrm{~F} 6$ and $\lambda 1 \mathrm{C} 2$ confirmed predictions that $\lambda 13 \mathrm{~F} 9$ and $\lambda 18 \mathrm{~B} 6$ should hybridize with the BE1 probe, and restriction analyses confirmed that the $\lambda 13 \mathrm{~F} 9$ and $\lambda 18 \mathrm{~B} 6$ inserts overlap the hybridizing regions cloned in the $\lambda$ PE 11 derivatives (Fig. 2). The discrepancy between the observed sizes of hybridizing fragments and the physical map ranged from 0.6 to $1.4 \mathrm{~kb}$ and, excluding experimental inaccuracies, it would seem that there is approximately $0.8 \mathrm{~kb}$ of extra DNA in the physical map relative to both the chromosomal and $\lambda$-cloned DNA (Fig. 3). When this discrepancy is taken into account, several of the fragments detected with one of the oligonucleotide probes could be placed, as shown in Fig. 3. 

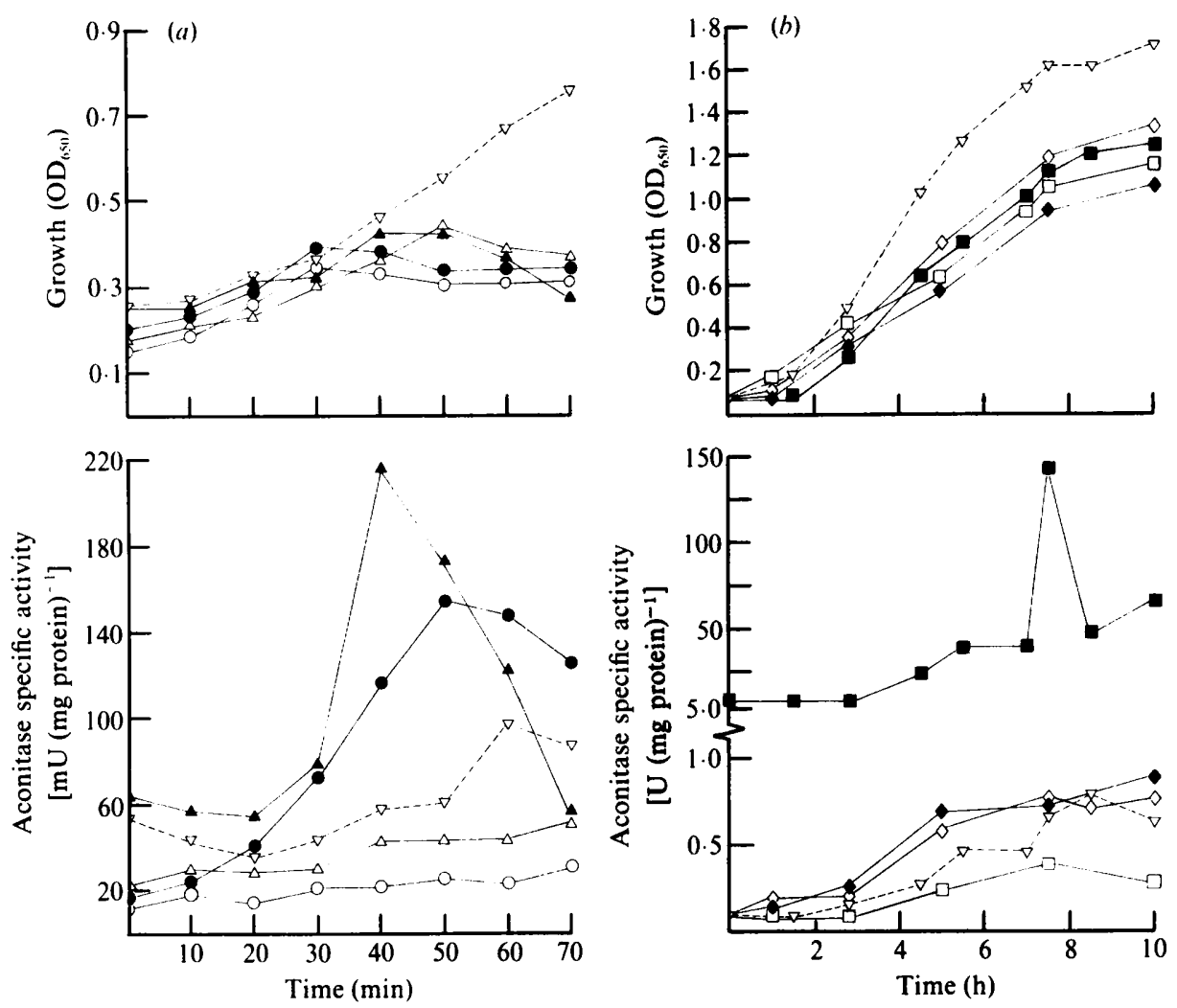

Fig. 4. Aconitase activities of $\lambda a c n$-infected and phagemid-containing $E$. coli. (a) The aconitase specific activities, $\mathrm{mU}\left(\mathrm{mg}\right.$ protein) ${ }^{-1}$, for $E$. coli $\mathrm{C} 600$ cultures infected with representative $\lambda$ PE11 and $\lambda$ EMBL4 derivatives (m.o.i. of 2 ) are shown below the corresponding growth curves; $\nabla$, uninfected;,$\lambda \mathrm{G} 229 ; O, \lambda \mathrm{G} 232 ; \Delta, \lambda 13 \mathrm{~F} 9 ; \triangle, \lambda 18 \mathrm{~B} 6$. The results obtained for $\lambda \mathrm{G} 230-231$ were similar to those for $\lambda \mathrm{G} 229$, and those for $\lambda \mathrm{G} 233-237$ to $\lambda \mathrm{G} 232$. (b) The aconitase specific activities, $\mathrm{U}$ (mg protein) ${ }^{-1}$, of transformants of $E$. coli DH1 grown in LB broth plus ampicillin $\left(200 \mu \mathrm{g} \mathrm{ml}^{-1}\right)$ are shown below the growth curves; $\nabla$, untransformed; $\bullet$ pUC119 (vector); $\diamond$, pUC445; $\square$, pGS447; and $\square$ pGS448. A representative set of typical and reproducible results is shown for each type of experiment.

\section{Biochemical characterization of putative גacn phages}

Evidence from enzymological and immunochemical studies with infected bacteria showed that four of the six types of phages containing the $400 \mathrm{bp}$ BamHI-EcoRI fragment (Fig. 2) possess an active acn gene. Aconitase activity was increased significantly and reproducibly after infection with $\lambda \mathrm{G} 229-231$ and $\lambda 13 \mathrm{~F} 9$ (represented by $\lambda \mathrm{G} 229$ and $\lambda 13 \mathrm{~F} 9$ in Fig. $4 a$ ) but not with $\lambda \mathrm{G} 232-237$ or $\lambda 18 \mathrm{~B} 6$. There were corresponding amplifications of immunopositive products co-migrating with aconitase $\left(M_{\mathrm{r}} 97500\right)$ from the active phages (Fig. 5). In addition, several cross-reacting fusion or deletion products were amplified with some of the inactive phages, e.g. $\lambda \mathrm{G} 232$, $M_{\mathrm{r}} 112000$ and $75000 ; \lambda \mathrm{G} 233-234, M_{\mathrm{r}} 67500 ; \lambda \mathrm{G} 235$, $M_{\mathrm{r}} 79000 ; \lambda \mathrm{G} 236, M_{\mathrm{r}} 72000 ; \lambda \mathrm{G} 237, M_{\mathrm{r}} 46000$ (Fig. 5).

These results indicate that the $400 \mathrm{bp} \mathrm{BamHI-EcoRI}$ fragment encodes part of aconitase, and that some of the immunopositive phages contain a functional acn gene despite the considerable rearrangement of bacterial DNA in the $\lambda$ PE1 1 library. Also, based on the calculated size of the acn coding region and the degree of similarity between the restriction maps of $\lambda \mathrm{G} 230-232, \lambda 13 \mathrm{~F} 9$ and $\lambda 18 \mathrm{~B} 6$, it is possible to define the approximate position of the acn gene in the $28 \mathrm{~min}$ region of the $E$. coli linkage map (Fig. 2). Furthermore, the polarity of the gene is defined by the relative positions of the binding sites for the hybridization probes, S135 (N-terminal) and BE1 (internal). It is not known whether $\lambda \mathrm{G} 233-237$ are immunopositive because they express part of the acn coding region, or some other product which cross-reacts with one of the antibodies used for immunodetection.

\section{Studies with a pUC119 derivative containing the acn gene}

Because the least corrupted DNA sources appeared to be cloned in $\lambda 13 \mathrm{~F} 9$ and $\lambda 18 \mathrm{~B} 6$, which contain overlapping inserts from the acn region, a fragment from each was combined in pUC119 in an attempt to reconstruct a functional acn gene. The strategy involved cloning the $1.08 \mathrm{~kb} \mathrm{BamHI}-$ PstI fragment of $\lambda 18 \mathrm{~B} 6$ in pUC119 to generate pGS445, and then inserting the $3.2 \mathrm{~kb} \mathrm{BamHI}$ 


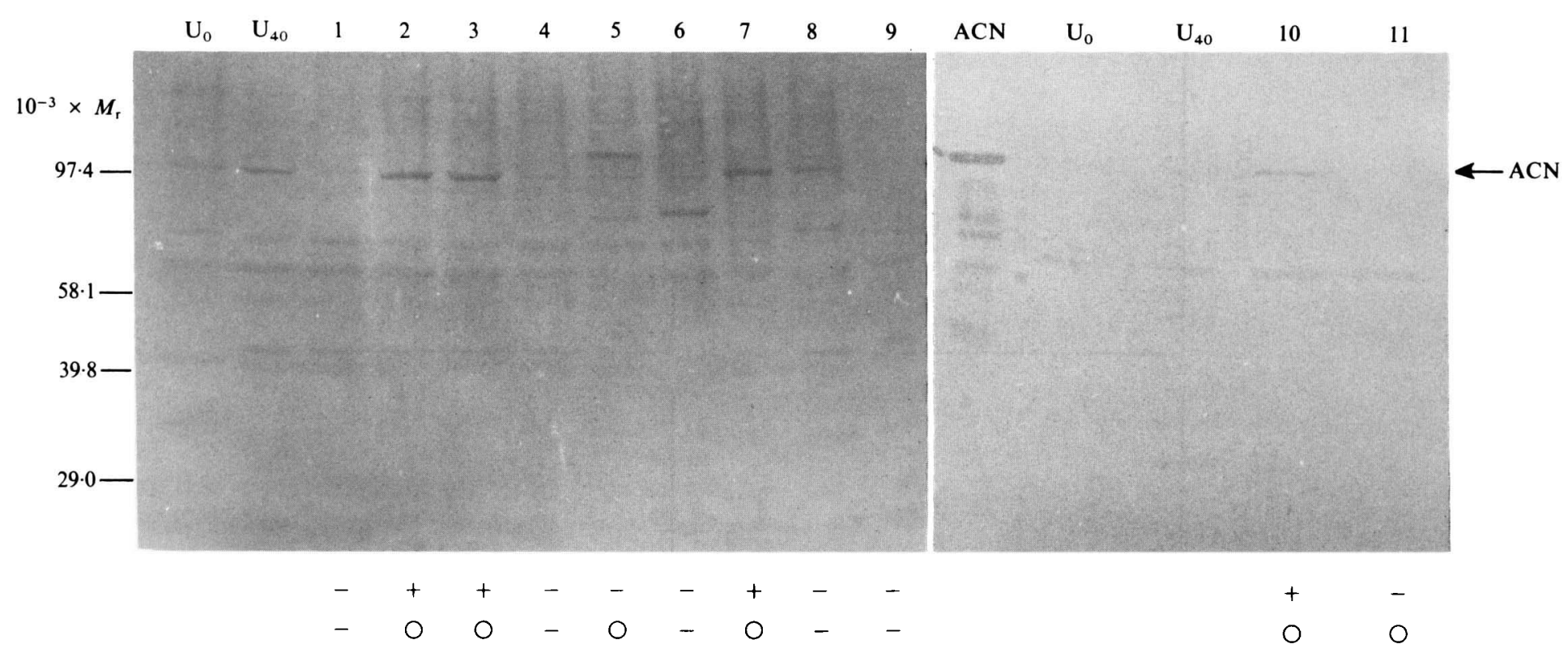

Fig. 5. Western blots of $E$. coli infected with putative $\lambda$ acn phages. Total cell protein in samples harvested after 40 min infection (see Fig. $4 a$ ) was fractionated by SDS-PAGE $(10 \%$ gel), blotted and immunostained. The presence of an amplified immunopositive product corresponding to aconitase (ACN), $M_{\mathrm{r}} 97500,(+)$, and the possession of the $400 \mathrm{bp}$ BamHI-EcoRI fragment $(\mathrm{O})$, are indicated. Lanes: $A C N$, purified aconitase; $U_{0}$ and $U_{40}$, uninfected bacteria at 0 and 40 min, respectively; $1-11$, bacteria infected with $\lambda \mathrm{G} 233$ (1), $\lambda \mathrm{G} 231$ (2) $\lambda \mathrm{G} 229$ (3), $\lambda \mathrm{G} 234$ (4), $\lambda \mathrm{G} 232$ (5), $\lambda \mathrm{G} 235$ (6), $\lambda \mathrm{G} 230$ (7), $\lambda \mathrm{G} 236$ (8), $\lambda \mathrm{G} 237$ (9), $\lambda 13 \mathrm{~F} 9$ (10) and $\lambda 18 \mathrm{~B} 6$ (11).

fragment of $\lambda 13 \mathrm{~F} 9$ into the unique $B a m H I$ site of pGS445 (Fig. 2). Phagemids containing the larger fragment in two orientations were recovered, pGS447 (desired orientation) and pGS448 (reverse orientation). The $3.2 \mathrm{~kb}$ Bam HI fragment was cloned in $\mathrm{M} 13 \mathrm{mp} 18$ to provide a probe (BB1) for screening transformants during the construction of pGS447 and pGS448.

The presence of a functional acn gene in pGS447 was confirmed by in vitro transcription-translation tests, enzyme analysis and immunochemical studies. In an in vitro expression system pGS447 directed the synthesis of a polypeptide of the size expected for the acn gene product $\left(M_{\mathrm{r}} 97500\right)$, a minor product of unknown origin $\left(M_{\mathrm{r}} 71000\right)$ and $\beta$-lactamase $\left(M_{\mathrm{r}} 30000\right)$ (data not shown). The aconitase specific activities were reproducibly 20-200-fold greater for E. coli DH1(pGS447) than for transformants containing pUC119, pGS445 or pGS448, at different stages in the growth cycle (Fig. $4 b$ ). Parallel SDS-PAGE analyses and Western blotting confirmed the dramatic enrichment of aconitase protein and cross-reacting material in the pGS447 transformant (Fig. 6). However, quantitative densitometry of Coomassie-stained gels indicated that the amount of aconitase protein in DH1(pGS447) remained relatively constant at $16-18 \%$ of total cell protein, throughout the short-lived, but reproducible, fourfold increase in specific activity in late exponential phase (Fig. $4 b$ ). With C600(pGS447) the specific activity increased somewhat earlier and more gradually to a similar maximum before declining, again with little change in aconitase protein (3.7-4.6\% of total). It would thus appear that a significant proportion of the aconitase can be in an inactive form and that a posttranslational activation-inactivation mechanism might be operating. It is also apparent that pGS448 expresses an enzymologically-inactive cross-reactive polypeptide of $M_{\mathrm{r}} 77000$ (Fig. 6) and, in keeping with the predicted location and polarity of the acn gene, this could correspond to an aconitase polypeptide which lacks a substantial C-terminal segment. The extra cross-reactive components observed in some of the DH1 transformants (Fig. 6) are presumably degradation products of aconitase which become apparent due to the high degree of aconitase amplification (pGS447), or to the instability of the truncated form (pGS448).

\section{Discussion}

The results describe the purification of aconitase from $E$. coli, the first cloning of a functional prokaryotic aconitase gene (acn), and the location and polarity of the $a c n$ gene at $28 \mathrm{~min}$ in the $E$. coli linkage map.

The aconitase of $E$. coli resembles those of other organisms in being monomeric and it is immunologically related to the porcine and Salmonella typhimurium enzymes. However, its size $\left(M_{\mathrm{r}} 97500\right)$ is significantly larger than the mitochondrial enzymes of porcine heart, 


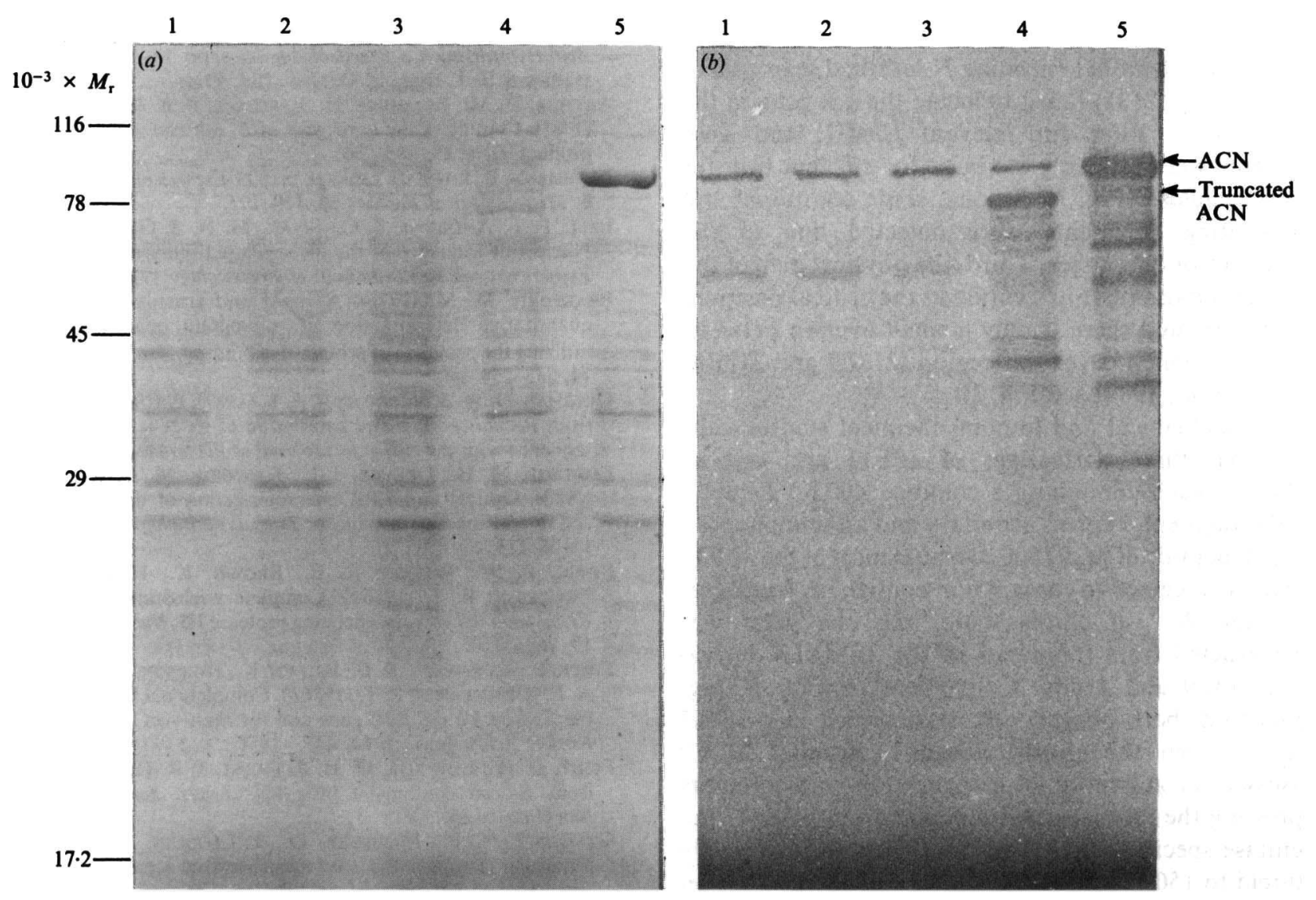

Fig. 6. SDS-PAGE analysis and Western blotting of total cell proteins of strains transformed with pUC119 derivatives. (a) Coomassiestained SDS-PAGE $(10 \%$ gel) of transformants of $E$. coli DH1 sampled at $7.5 \mathrm{~h}$ (see Fig. $4 b$ ). The positions of biotinylated molecular mass markers are indicated, as are the positions of aconitase (ACN) and a truncated derivative (arrows). (b) Immunostained Western blot of samples fractionated as in (a). Lanes: 1, untransformed host; 2-5, specific transformants with phagemids pUC119 (2), pGS445 (3), pGS448 (4) and pGS447 (5).

bovine heart and $S$. cerevisiae $\left(M_{\mathrm{r}} 79000-83000\right)$, and smaller than the $B$. subtilis and Sal. typhimurium enzymes $\left(M_{\mathrm{r}} 120000\right.$ approx.) The $\mathrm{N}$-terminal sequences of the $a c n$ and $c i t B$ products are sufficiently similar to suggest that these proteins are homologous. If this is substantiated, the $E$. coli enzyme will join the family of mammalian, yeast and Bacillus enzymes (Zheng et al., 1990; Gangloff et al., 1990; Dingman \& Sonenshein, 1987). In the case of fumarase, $E$. coli contains two classes of enzyme, of which only one is related to the Bacillus and mitochondrial enzymes. It will therefore be interesting to discover whether an analogous situation exists for aconitase. Despite the similarities in $\mathrm{N}$ terminal sequence, the corresponding segment of the cit $B$ structural gene failed to detect the acn gene of $E$. coli when used as a heterologous probe. Weak hybridization to the recC and ptrIII genes was detected, and to the lac region (presumably because the probe was contaminated with lac DNA). However, the reason why aconitase is amplified up to 18-fold upon induction of several putative $\lambda$ acn prophages, which were later shown to contain inserts from the lac region, remains obscure (Wilde et al., 1986; Wilde, 1988).

Citrate was used to protect aconitase during purification, but $99.4 \%$ of the activity was still lost. In the final step the active and inactive enzymes were resolved because the latter failed to bind to the Procion Red matrix. Presumably, the poor recoveries of active and inactive enzyme were due to the inherent instability of the enzyme and to the removal of the inactive form at each stage.

The successful cloning strategy involved raising antibodies to purified aconitase for the immunodetection of $\lambda$ acn phages, and the acn gene was located at $28 \mathrm{~min}$ $(1350 \mathrm{~kb})$ in the physical map using a fragment of the gene as a hybridization probe. As a result, all of the citric acid cycle genes of $E$. coli have now been cloned and located in the chromosome. Of these, the acn gene is closest but not adjacent to the isocitrate dehydrogenase gene (icd) at 25 min (Kroger et al., 1990; Bachmann, 
1990). There seem to be several reasons why the mixed oligonucleotide probes encoding $\mathrm{N}$-terminal segments of aconitase (e.g. S135) failed to locate the acn gene in the physical map. First, the relevant HindIII and KpnI fragments were probably too large for efficient transfer to nitrocellulose (Fig. 3). Second, some additional and complicating fragments were detected due to the degeneracy of the probes. Third, the physical map of the E. coli chromosome is inaccurate at the critical position, possibly because there is only a small overlap between the phages which cover this region $(\lambda 13 \mathrm{~F} 9$ and $\lambda 18 \mathrm{~B} 6$; Kohara et al., 1987; see Fig. 2).

The biochemical and immunochemical studies indicated that three derivatives of $\lambda$ PE 11 and one of $\lambda E M B L 4$, each containing a common 400 bp BamHIEcoRI fragment, express aconitase and an immunopositive polypeptide of $M_{\mathrm{r}} 97500$. Because most of the $\lambda$ PE11 derivatives seemed to contain non-contiguous fragments from the $E$. coli chromosome, the acn gene was reconstructed from fragments of the $\lambda E M B L 4$ derivatives, $\lambda 13 \mathrm{~F} 9$ and $\lambda 18 \mathrm{~B} 6$. Convenient restriction fragments from both phages were recombined in pGS447 (Fig. 2) even though it seemed likely that $\lambda 13 \mathrm{~F} 9$ possessed an active intact acn gene. In transformants expressing the reconstructed acn gene from pGS447 the aconitase specific activity was amplified approximately 200-fold to $150 \mathrm{U}$ (mg protein $)^{-1}$ and aconitase protein increased to 4.6 or $18 \%$ of total cell protein, depending on the strain. There appeared to be disproportionate changes in activity relative to protein content during the course of the growth cycle, as if a post-translational activation-inactivation mechanism may be operating. This could reflect the intracellular redox-state and ironavailability at the corresponding stages in the growth cycle. Nevertheless, the potential for enzyme amplification with pGS447 should lead to greatly improved yields of purified enzyme as well as facilitating studies on the incorporation of iron and other enzymological properties. Current work is focussed on deriving the nucleotide sequence of the acn gene and investigating mutants constructed by replacing the chromosomal gene with an in vitro-disrupted derivative.

\footnotetext{
We are very grateful to D. Buck, Y. Kohara, P. T. Emmerson and M. Masters for supplying phages and bacterial strains, S. C. Andrews for assistance with immunological methods, W. W. Kay for helpful advice, and J. B. C. Findlay and J. Keen for deriving the N-terminal amino acid sequence of aconitase. The work was supported by the Leverhulme Trust and the Science and Engineering Research Council, and we are also indebted to Dr W. J. E. Gardner and Haarmann \& Reimer (Selby) for their participation in a SERC-CASE studentship (M.J.H.).
}

\section{References}

Andrews, S. C., Harrison, P. M. \& Guest, J. R. (1989). Cloning, sequencing, and mapping of the bacterioferritin gene (bfr) of Escherichia coli K-12. Journal of Bacteriology 171, 3940-3947.
Arrand, J. E. (1985). Preparation of nucleic acid probes. In Nucleic Acid Hybridization, a Practical Approach, pp. 17-45. Edited by B. D. Hames \& S. J. Higgins. Oxford: IRL Press.

arthur, H. M., Bramhill, D., Eastlake, P. B. \& Emmerson, P. T. (1982). Cloning of the $u v r D$ gene of $E$. coli and identification of the product. Gene 19, 285-295.

BaChMANN, B. J. (1990). Linkage map of Escherichia coli K-12, edition 8. Microbiological Reviews 54, 130-197.

Bell, P. J., Andrews, S. C., Sivak, M. N. \& Guest, J. R. (1989). Nucleotide sequence of the fnr-regulated fumarase gene ( fumB) of Escherichia coli K-12. Journal of Bacteriology 171, 3494-3503.

BRADFORD, M. M. (1976). A rapid and sensitive method for the quantitative determination of microgram quantities of protein utilizing the principle of protein-dye binding. Analytical Biochemistry 72, 248-254.

Dingman, D. W. \& Sonenshein, A. L. (1987). Purification of aconitase from Bacillus subtilis and correlation of its N-terminal amino acid sequence with the citB gene. Journal of Bacteriology 169, 3062-3067.

Emptage, M. H., Dreyer, J.-L., KenNedy, M. C. \& Beinert, H. (1983). Optical and EPR characterization of different species of active and inactive aconitase. Journal of Biological Chemistry 258, 11106-11111.

Finch, P. W., Wilson, R. E., Brown, K., Hickson, I. D. \& Emmerson, P. T. (1986a). Complete nucleotide sequence of the Escherichia coli ptr gene encoding protease III. Nucleic Acids Research 19, 7695-7703.

Finch, P. W., Wilson, R. E., Brown, K., Hickson, I. D., Tomkinson, A. E. \& Emmerson, P. T. $(1986 b)$. Complete nucleotide sequence of the Escherichia coli recC gene and the thy A-recC intergenic region. Nucleic Acids Research 14, 4437-4451.

Flint, D. H., EmptaGe, M. H. \& Guest, J. R. (1989). Fumarase A from $E$. coli contains a [4Fe-4S] cluster. Journal of Inorganic Biochemistry 36, 306.

Gangloff, S. P., Marguet, D. \& Lauquin, G. J.-M. (1990). Molecular cloning of the yeast mitochondrial aconitase gene ( $\mathrm{ACOI}$ ) and evidence of a synergistic regulation of expression by glucose plus glutamate. Molecular and Cellular Biology 10, 3551-3561.

Gray, C. T., WimpenNy, J. W. T. \& Mossman, M. R. (1966). Regulation of metabolism in facultative bacteria. II. Effects of aerobiosis and nutrition on the formation of Krebs cycle enzymes in Escherichia coli. Biochimica et Biophysica Acta 117, 33-41.

KENNEDY, M. C. \& BieneRT, H. (1983). The state of cluster SH and $\mathrm{S}^{2-}$ of aconitase during cluster interconversions and removal. Journal of Biological Chemistry 263, 8194-8198.

KenNedy, M. C., EmptaGe, M. H., Dreyer, J.-L. \& Bienert, H. (1983). The role of iron in the activation-inactivation of aconitase. Journal of Biological Chemistry 258, 11098-11105.

Kennedy, M. C., Werst, M., Telser, J., Emptage, M. H., Beinert, H. \& HOFFMAN, B. M. (1987). Mode of substrate carboxyl binding to the $[4 \mathrm{Fe}-4 \mathrm{~S}]^{+}$cluster of reduced aconitase as studied by ${ }^{17} \mathrm{O}$ and ${ }^{13} \mathrm{C}$ electron-nuclear double resonance spectroscopy. Proceedings of the National Academy of Sciences of the United States of America 84, 8854-8858.

Kohara, Y., AkiYama, K. \& Isono, K. (1987). The physical map of the whole $E$. coli chromosome: application of a new strategy for rapid analysis and sorting of a large genomic library. Cell 50, 495-508.

Kroger, M., WaHL, R. \& Rice, P. (1990). Compilation of DNA sequences of Escherichia coli (update 1990). Nucleic Acids Research 18, 2549-2587.

LAEMMLI, U. K. (1970). Cleavage of structural proteins during the assembly of the head of bacteriophage T4. Nature, London 277, 680685 .

LAURSEN, R. A. (1971). Solid phase Edman degradation: an automated peptide sequencer. European Journal of Biochemistry 20, 89-102.

Maniatis, T., Fritsch, E. F. \& SAmbrook, J. (1982). Molecular Cloning, a Laboratory Manual. Cold Spring Harbor, NY: Cold Spring Harbor Laboratory.

Mason, P. J. \& Williams, J. G. (1985). Hybridization analysis of DNA. In Nucleic Acid Hybridization, a Practical Approach, pp. 113137. Edited by B. D. Hames \& S. J. Higgins. Oxford: IRL Press.

MeINKoth, J. \& WAHL, G. (1984). Hybridization of nucleic acids immobilized on solid supports. Analytical Biochemistry 138, 267-284. 
Miles, J. M. \& GuEST, J. R. (1987). Molecular genetic aspects of the citric acid cycle of Escherichia coli. Biochemical Society Symposia 54, 45-65.

Robbins, A. H. \& Stout, C. D. (1989a). The structure of aconitase. Proteins 5, 289-312.

RobBins, A. H. \& STouT, C. D. $(1989 b)$. Structure of activated aconitase: Formation of the [4Fe-4S] cluster in the crystal. Proceedings of the National Academy of Sciences of the United States of America 86, 3639-3643.

Rosenkrantz, M. S., Dingman, D. W. \& Sonenshein, A. L. (1985). Bacillus subtilis citB gene is regulated synergistically by glucose and glutamine. Journal of Bacteriology 164, 155-164.

RYDEN, L., OfVerstedT, L., BEINERT, H., EMPTAGe, H. \& KenNedy, M. C. (1984). Molecular weight of beef heart aconitase and stoichiometry of the components of its iron-sulfur cluster. Journal of Biological Chemistry 259, 3141-3144.

ScHolze, H. (1983). Studies on aconitase species from Saccharomyces cerevisiae, porcine and bovine heart, obtained by a modified isolation method. Biochemica et Biophysica Acta 746, 133-137.

SOUTHERN, E. (1975). Detection of specific sequences among DNA fragments separated by gel electrophoresis. Journal of Molecular Biology 98, 503-517.

Suzuki, T., Yamazaki, O., Nara, K., AkiYama, S.-I., NakaO, Y. \& FUKUDA, H. (1975). The aconitase of yeast: II. crystallization and general properties of yeast aconitase. Journal of Biochemistry 77, 367-372.

Villafranca, J. J. \& Mildvan, A. S. (1971). The mechanism of aconitase action. Journal of Biological Chemistry 246, 772-779.

WeRst, M. M., KenNedy, M. C., BieneRT, H. \& Hoffman, B. M. $(1990 a) .{ }^{17} \mathrm{O},{ }^{1} \mathrm{H}$, and ${ }^{2} \mathrm{H}$ electron double resonance characterization of solvent, substrate, and inhibitor binding to the $[4 \mathrm{Fe}-4 \mathrm{~S}]^{+}$cluster of aconitase. Biochemistry 29, 10526-10532.

Werst, M. M., KenNedy, M. C., Bienert, H., Houseman, A. L. P. \& HoffMan, B. M. $(1990 b)$. Characterization of the [4Fe-4S] cluster at the active site of aconitase by ${ }^{57} \mathrm{Fe},{ }^{33} \mathrm{~S}$, and ${ }^{14} \mathrm{~N}$ electron double resonance spectroscopy. Biochemistry 29, 10533-10540.

WILDE, R. J. (1988). PhD Thesis, University of Sheffield.

Wilde, R. J., Jeyaseelan, K. \& Guest, J. R. (1986). Cloning of the aconitase gene (acn) of Esherichia coli. Journal of General Microbiology 132, 1763-1766.

Woods, S. A., Schwartzbach, S. D. \& Guest, J. R. (1988). Two biochemically distinct classes of fumarases in Escherichia coli. Biochimica et Biophysica Acta 954, 14-26.

Zheng, L., Andrews, M. A., Hermodson, M. A., Dixon, J. E. \& ZALKIN, H. (1990). Cloning and structural characterization of porcine heart aconitase. Journal of Biological Chemistry 26, 28142821. 